\title{
The Role of Teacher's Self-efficacy as a Predictor of Iranian EFL Teacher's Burnout
}

\author{
Mona Tabatabaee Yazdi \\ Department of English, Torbat-e-Heydarieh Branch, Islamic Azad University, Iran \\ Khalil Motallebzadeh \\ English Department, Islamic Azad University, Torbat-e-Heydarieh Branch, Iran \\ Hamid Ashraf \\ English Department, Islamic Azad University, Torbat-e-Heydarieh Branch, Iran
}

\begin{abstract}
In foreign language setting, there are some social psychological variables that can highly influence on the teachers' and learners performance. One of these important variables in language pedagogy is Selfefficacy "an individual's confidence in his/her ability to engage in the social interactional tasks necessary to initiate and maintain interpersonal relationships" (Bandura, 2006). Another influential factor that is importance in teaching contexts is burnout. Burn out is defined as a result of long term job-related stress, especially among human service workers such as teachers (Jennett, Harris, \&Mesibov, 2003). This study, which utilized qualitative _ quantitative methodologies, aimed at measuring the relationship between the self-efficacy of Iranian English teachers and their feelings of burnout. The needed data were gathered through the application of the two questionnaires: The Maslach Burnout Inventory (MBI; Maslach \& Jackson 1981, 1986) and a researchersmade questionnaire of self-efficacy. The participants are as 616 professional experienced teachers from both genders and different age groups, having university education from different provinces of Iran. The SPSS software (version 16) was used to change the data into numerical interpretable data. To determine the relationship between self-efficacy and teachers' burnout, correlational analysis was employed. The result showed that the participants' self-efficacy has a reverse relationship with their burnout. In addition, a significant relationship was observed between teachers' reports of burnout, and their years of experiences.
\end{abstract}

Index Terms-burnout, self-efficacy, ELT teachers

\section{INTRODUCTION}

Stress and intension seems to be of the most challenging features of professional life these days. Researcher's studies confirmed that stress is an important influential factor of all contexts and work places. There is significant studies confirmed that stress is an important influential factor of all contexts and work places. There is significant evidence that interpersonal support at work, particularly from the school principal, plays a key role in highlighting job stress and burnout in teachers (Leithwood, Menzies, Jantzi, \&Leithwood, 1996).

Jennett, Harris, and Mesibov, 2003, defined burnout as a result of long term occupational stress, especially among human service workers such as teachers (Jennett, Harris, Mesibov, 2003).

As cited in Martin, Sass, and Schmitt, 2012, teacher intended-to-leave is very harmful to the profession. In the United States almost about one quarter of novice educators are not willing to continue their job after three years and by the fifth year this increases to 40\%. (Milner \&Woolfolk Hoy, 2003; National Center for Education Statistics, 2004; National Commission on Teaching and America's Future, 2003)

Another significant factor in any job success is self-efficacy that could be defined as people beliefs about their own abilities to think, plan, monitor, organize, and perform activities needed in educational settings (Bandura 1997, 2006).

This study aimed at investigating the extent to which teachers participating in their teaching classes leads to teacher burnout. Furthermore, the link between EFL teachers' self-efficacy and their burnout were examined with regard to demographics.

Researchers in this study try to find out how Iranian EFL teachers' self-efficacy is related to their burnout. Consequently, this study addresses the following research questions:

1) Is there any significant relationship between teachers' self-efficacy, and their feelings of burnout?

2) Is there any significant relationship between teachers' burnout with regard to their level of qualification?

3) Is there any significant relationship between teachers' burnout and their field of the study?

\section{LITERATURE REVIEW}

In any classroom settings, one important question may always be raised: why some of teachers could tolerate the high level of stress and succeed in their job while some others could not stand expectations imposed on them. The first 
reason may be teacher self-efficacy as a belief in one's ability (Gavora, 2011). This kind of belief affects on ones feeling and related to hopelessness, anxiety, and depression. Another reason may lie in teacher burnout that is caused by a number of negative factors, including low levels of self-efficacy.

\section{A. Teachers' Burnout}

Freudenberger (1974) coined the term "burnout"' as the result of long time hard working and overextension. As cited in Devos, Dupriez \&Paquay, 2012, the first years of teaching are a difficult period. Inexperienced teachers come into a novel world; meet new things, unexpected condition and challenges. They are going to meet dissimilar types of difficulties and problems, such as controling classroom discipline, assessing learners' work, motivating learners (Britt, 1997; Ganser, 1999; Melnick\& Meister, 2008; Veenman, 1984). Still, while this initial stage is frightening for some, it is a satisfying experience for others (Hebert \& Worthy, 2001). How could this be clarified?

Besides the individual characteristics of the novice teachers, the social working conditions (e.g. relationships with colleagues,) is a key for understanding how teachers deal with this difficult period.

Schutz and Zembylas (2009) believe that high attrition rates among novice teachers might be "related to the emotional nature of the teaching profession" (p. 3). In addition, according to Nias (1996) feelings are firmly connected to cognitions, social and cultural environment, and "the fiercest of their negative emotions are currently caused by interactions with peers or superiors rather than students" (p. 295). In addition, negative and harmful emotions (i.e. depression) lead teachers to leave their job (Frenzel, Goetz, Stephens, \& Jacob, 2009; Schutz\&Zembylas, 2009).

Schonfeld (1992) as a result of a longitudinal study believed that work setting (such as unmotivated students, overcrowded classrooms) could be a predictor of teachers' willingness to continue their job.

Teacher stress has known as a global concern, taking into consideration that about a third of the teachers participating in a variety of studies around the world stated that they considered teaching as extremely stressful (Borg, 1991).

Recently, Akbari and Moradkhani (2010) explored relationship between teaching experience, and teacher efficacy among 447 Iranian EFL teachers. The results showed that experienced teachers experienced a significantly higher level efficacy.

As cited in Bruce 2009, "Strategies to avoid burnout include reducing stress, keeping personal health strong, building a strong social network, obtaining clear expectations in all facets of one's professional life, improving time management, participating in a mentoring program, and self-reflecting on personality characteristics that may be contributing to stress and burnout." (p. 57)

\section{B. Teachers' Self-efficacy}

More than a century ago, Dewey (1903) argued that all teachers should have "some regular and representative way in which he or she can register judgment upon matters of educational importance, with the assurance that this judgment will somehow affect the school system" (p. 199).

Bandura (1997) proposed self-efficacy as perceived “... beliefs in one's capabilities to organize and execute the courses of action required to produce given attainments" (p. 3).

Social cognitive theory suggested that a school's cultural environment affect individual self-efficacy. For instance, research proposed that school environment, or "teachers' perceptions of psychosocial dimensions of the environment of the school"' (Rentoul\& Fraser, 1983, p. 21) are certainly associated to teachers' feelings of efficiency (Hoy, 1996) and may be not positively related to burnout (Trent, 1997) and turnover (Norton, 1998).

Teacher's self-efficacy form how teachers behave in their classes and have a great impact on the learning setting and environment. The ability of teachers to provide a supportive condition for learners and motivating them (even struggling learners) shows that teachers are significantly important to the extent their learners are attending to and interested in the lesson(Pines, 2002).

Markley (2004, as cited in Ghasemi\&Hashemi, 2011) stated about the important role of English language teachers in their academic success and learners' learning that highly depends on teachers and their methodologies in their classes.

Teachers' methodologies and their actions in the class and the way they recognize and arrange instruction extremely related to their ideologies of successful teaching and their ideas about teacher efficacy (Ghaith\&Shaaban, 1999; Chacón, 2005).

Then, the teachers' ideas of a successful teacher can extremely affect their teaching and accordingly their learners' learning (Dembo\& Gibson, 1985; Goddard, Hoy, \& Hoy, 2000).

It is assumed that teacher's self-efficacy may decrease if teacher believes that factors like students' ability and home environment are of more importance to learning than the teachers' influences. However, Rotter (1966) maintained that teacher self-efficacy increase if teachers believe that education could influence learners' behavior and progress.

Rots et al. (2007) maintain that the basis of teachers' turnover could be found in the quality of early teacher experience and novice teacher commitment. There are also researches that propose the practice time is the most powerful part in teacher education (Roness\& Smith, 2010; Smith \& Lev-Ari, 2005; Wilson, Floden, \&Ferrini-Mundi, 2002).

Further, Vaezi and Fallah (2011) explored the connection between self-efficacy and anxiety in a sample of Iranian EFL teachers in private language institutes. The results showed an important negative correlation between self-efficacy and stress. 
Akbari and Moradkhani, 2010, studied relationship between teaching experience, academic degree and teacher efficacy among 447 Iranian EFL teachers. The results of data analysis revealed that experienced teachers (with more than three years of teaching experience) had a significantly higher level of efficacy, efficacy for classroom management, efficacy for student engagement, and efficacy for instructional strategies compared to their novice counterparts.

\section{Methodology}

\section{A. Participants}

Participants of this study were 616 EFL teachers from different provinces of Iran. Selection was done from all available subjects who were considered as professional experienced teachers having university education (Bachelor: 353; Master: 253 and PhD: 10). They were both males (199) and females (417) and aged between 20 and +40 years old with a range of between -1 and +10 years of teaching experience. Their field of study was TEFL (419), English Translation (156), and English literature (41). All of them were supposed to pass TTC whether in University or Institute.

\section{B. Instruments}

The needed data for this study were gathered through the application of one standard and one modified questionnaires: The Maslach Burnout Inventory (MBI; Maslach \& Jackson 1981, 1986) and a researchers-made questionnaire of self-efficacy. In addition, demographic form asked about the participants 'demographic information including age, gender, province, and years of teaching experience.

\section{Teacher's burnout scale}

The Maslach Burnout Inventory (MBI; Maslach\& Jackson 1981, 1986) that is one of the universal instruments used for assessing burnout was used in this study. The questionnaire consisted of three sub-dimensions; emotional exhaustion sub-dimension (EE, 9 items, maximum score - 54), desensitization sub-dimension (D, 5 items, maximum score - 30), and personal accomplishment sub dimension (PA, 8 items, maximum score - 48). Higher emotional exhaustion and desensitization sub-dimensions and lower personal accomplishment sub-dimensions cause high burnout status (Maslach\& Jackson, 1981).

Prior research confirmed the validity, reliability of this questionnaire (Iwanicki\&Schwab, 1981; Gold, 1985). Additionally, reliabilities for data gathered from each of the three scales ranged from .76 to .90 (Iwanicki \& Schwab, 1981) and .72 to .88 (Gold, 1985). Reliabilities for data in the present study were similar and acceptable (EE: .89, DP: .71, PA: .71).

\section{Teacher's self-efficacy scale}

For measuring teachers' self-efficacy a researchers made questionnaire was designed based on the (TschannenMoran \&Woolfolk-Hoy 2001)and (Bandura, 1997) Instrument Teacher Self-efficacy Scale, and (Murdoch,1997) Good Teacher's questionnaire.

This 30-item researcher- made questionnaire was conducted according to the following 5 subscales: efficacy to influence decision making ( 2 items, maximum scores _ 10), instructional efficacy (15 items, maximum score - 45), disciplinary efficacy ( 2 items, maximum score -10$)$, efficacy to enlist parental and community involvement ( 3 items, maximum score - 15), and efficacy to create a positive school climate( 8 items, maximum score -40$)$. Each item is measured on a 5-point scale: "nothing, very little, some influence, quite a bit, a great deal."

Two experts in the area of ELT validated the questionnaire and the reliability was estimated using Cronbach's Alpha .9.

\section{Procedure}

In this study, 616 participants who are all Iranian ELT teachers in different language schools from different cities were selected. They were from both genders and from different ages with different years of experiences. They were selected according to Morgan's table of sampling and based on availability of subjects.

Surveys are usually conducted by using interviews or questionnaire or both. In this study, for collecting the data, questionnaires in the form of papers and online (using Google drive) were spread up to different English Language teachers of different ages and years of experiences to answer the questions. These teachers were from different subfields of the study within English Language field. Most of them were almost from six big provinces of Iran (Tehran, Semnan, Khorasan Razavi, Yazd, Bandar Abas, Qom and others). Collecting data started at April 2013 and lasted for about 3 weeks. The probable needed time for filling out both questionnaires was about 10 minutes.

Gathering data was summarized by the use of SPSS software. Then, the correlation between these two variables was calculated.

\section{RESUlT}

Table (1) presents categorization of sub-scales of burnout and self-efficacy scales and their related Cronbach Alpha reliability coefficients based on the data collected from the 616 participants of the study. 
TABLE 1.

\begin{tabular}{|c|c|c|}
\hline Scales/sub-scales & & $(\alpha)$ \\
\hline \multicolumn{3}{|l|}{ Burnout } \\
\hline Emotional Exhaustion & $1,4,9,10,15,16,18,20,22$ & .89 \\
\hline Reduced Personal Accomplishment & $3^{*}, 6^{*}, 7^{*}, 12^{*}, 13^{*}, 17^{*}, 19^{*}, 21^{*}$ & .71 \\
\hline Depersonalization & $2,5,8,11,14$ & .71 \\
\hline \multicolumn{3}{|l|}{ Self-efficacy } \\
\hline Efficacy to Influence Decision Making & 1,2 & .82 \\
\hline Instructional Efficacy & $3,4,5,6,7,8,9,10,11,12,13,14,15,16,17$ & .87 \\
\hline Disciplinary Efficacy & 18,19 & .71 \\
\hline Efficacy to Enlist Parental and Community Involvement & $20,21,22$ & .71 \\
\hline Efficacy to Create a Positive School Climate & $23,24,25,26,27,28,29,30$ & .74 \\
\hline
\end{tabular}

* Scored in reverse order

Pearson product-moment correlation was conducted to examine the role of teachers' self-efficacy in their burnout. The results indicated significant negative correlations between self-efficacy and burnout $(\mathrm{r}=-0.61, \mathrm{p}<0.01)$. This is in accordance with Vaezi and Fallah (2011) that explored a significant negative correlation between self-efficacy and job stress among a sample of Iranian EFL teachers in private language institutes.

Moreover, as table 2 revealed all sub-scales of teacher self-efficacy were negatively correlated with teachers' burnout as follows: burnout and (1) efficacy to influence decision making $(r=-0.21, p<0.00)$, and (2) instructional efficacy ( $r=$ $-0.61, \mathrm{p}<0.01)$, (3) disciplinary efficacy $(\mathrm{r}=-0.46, \mathrm{p}<0.01)$, (4) efficacy to enlist parental and community involvement, $(r=-0.30, \mathrm{p}<0.01)$ and $(5)$ efficacy to create a positive school climate $(\mathrm{r}=-0.51, \mathrm{p}<0.01)$.

TABLE 2.

CORRELATION BETWEEN TEACHERS' SELF_EFFICACY AND BURNOUT

\begin{tabular}{lc}
\hline Burnout & $(\mathrm{r})$ \\
\hline Total Self-efficacy & $-0.58^{* *}$ \\
Efficacy to Influence Decision Making & $-0.26^{* *}$ \\
Instructional Efficacy & $-0.60^{* *}$ \\
Disciplinary Efficacy & $-0.46^{* *}$ \\
Efficacy to Enlist Parental and Community Involvement & $-0.34^{* *}$ \\
Efficacy to Create a Positive School Climate & $-0.43^{* *}$ \\
\hline
\end{tabular}

In addition, two components of teacher's burnout, namely Emotional Exhaustion, and Depersonalization were negatively correlated with teachers' self-efficacy as follows: self-efficacy and (1) Emotional Exhaustion $(r=-0.49$, $p<$ 0.01), and (2) Depersonalization ( $\mathrm{r}=-0.52, \mathrm{p}<0.01)$, but the third component, namely (3) Reduced Personal Accomplishment, is positively correlated with teachers' self-efficacy $(\mathrm{r}=-0.43, \mathrm{p}<0.01)$.

These findings are similar to the study of Hakanen, Bakker and Schaufeli (2006) that revealed both emotional exhaustion and depersonalization correlated negatively with turnover and health among Finnish teachers.

On the other hand, a positive relationship was found between personal achievement and self-efficacy $(\mathrm{r}=.54, \mathrm{p}<.001)$. The increase in feeling of success among the teachers leads to an increase in self-efficacy. Moreover negative relationship was found between depersonalization and self-efficacy $(r=.43, p<.001)$.

To analyze the data further, linear regression analysis was conducted to find out to what extent self-efficacy might have predictive rule in teachers' overall burnout.

The results indicated that teachers' total score of self-efficacy was a negative predictor of the dependent variable. In this analysis, Total Self-efficacy and its constructs explained $40 \%$ of the variance in teachers' burnout. Of these variables Instructional self-efficacy made the largest unique contribution $($ Beta $=-.46$, sig. $=0.000$, part $=-.29)$ and Efficacy to create a positive school climate also made a statistically significant contribution $($ Beta $=-.15$, sig. $=0.000$, part $=-.1)$.

Considering different provinces, the results revealed significant negative correlations between self-efficacy and burnout in Tehran $(r=-0.62, p<0.01)$, Khorasan-Razavi $(r=-0.58, p<0.01)$, Yazd $(r=-0.76, p<0.01)$, Bandar Abas $(r=-0.65, p<0.01)$, Semnan $(r=-0.73, p<0.01)$, and others $(r=-0.69, p<0.01)$.

These indicated that the higher significant negative correlation in case of province was for Yazd, and there was no significant correlation between teachers' burnout and their self-efficacy in Qom province $(\mathrm{r}=-0.22, \mathrm{sig}=0.9, \mathrm{p}>0.05)$.

Results of the study revealed significant correlation at the level of B.A. $(r=-0.51, p<0.01)$ and higher in male teachers. Also the correlation is significant at the M.A. level $(r=-0.73, p<0.01)$, and higher in females. However, the correlation is not significant in PhD level $(r=-0.15$, sig $=0.7, p>0.01)$. Therefore, these findings and the following tables revealed feeling of burnout was higher for M.A. teachers and no sign of burnout for PhD teachers.

Moreover, considering teachers' field of the study, the result showed a significant negative correlation between teachers' burnout and their self-efficacy as follow: TEFL $(r=-0.64, p<0.01)$, English translation $(r=-0.52, p<0.01)$, and English Literature $(\mathrm{r}=-0.64, \mathrm{p}<0.01)$. Moreover, analysis showed that correlation was higher in male teachers in TEFL, but higher for female teachers in 2 other fields. 
In addition, qualitative data that gathered using two open-ended questions revealed that there was similarities among the teachers both in how burdened they felt and how it might be prevented.

The teachers perceived financial issues as being the most demanding and problematic element of their work in terms of burnout (27\%), for example, one teacher stated that "payment principles don't appreciate your efforts."

Moreover, Open-ended questions showed that many teachers believed in lack of self-confidence and motivation as the reasons of burdening $(12.8 \%)$. Several teachers believed that they had some trouble with the materials and books they taught $(10 \%)$, for example "use of inappropriate methodology for the subject being taught is one of the main reasons."

A lack of professional and qualified teachers, educational rules and policies, not positive and friendly atmosphere among colleagues/supervisors and managers, students with behaviour problem and not qualified supervisors and managers were characteristic of the reasons that were considered as burdening by the teachers.

\section{DISCUSSION}

The purpose of the present study was to investigate the relationship between self-efficacy and burnout among Iranian EFL teachers in private language institutes. Moreover, demographic variables including teachers' field of the study and their level of qualification were considered to determine any significant effect of them on teachers' burnout. The results indicated significant negative relationship between teacher self-efficacy and burnout. This finding is in agreement with previous theoretical studies on the role of self-efficacy in burnout (e.g. Zamani Rad, \& Rohany, 2010; Vaezi, Fallah 2011; Devos, \& Paquay, 2012). The size of this correlation indicates that the higher the teachers' self-efficacy, the less likely they are to experience burnout.

The findings proposed that some EFL teachers, mainly younger feel more success in their profession, and they could be more successful at reducing the level of burnout. This may have suggestions for teachers' well-being, motivation and teaching efficiency and accordingly emphasize the value of setting up some courses for EFL teachers to increase efficacy.

It was also found that there was significant difference in the teachers' self-efficacy and feeling of burnout with respect to teachers' field of the study and their level of qualification.

The results also indicated a negative correlation between EFL teachers' self-efficacy and years of teaching experience, as well as age. In other words, teachers' self-efficacy tends to decrease over time and with every year of teaching. This is not in accordance with findings of Chester and Beaudin(1996) who revealed that beliefs are mediated by the teachers' age and prior experience. These results were also in contrast with those of Campbell (1993) who showed teachers with more experience were more efficacious.

Furthermore, qualitative data suggested that there was similarities among the teachers both in how burdened they felt and how it might be prevented. The teachers accounted different kinds of reasons causing burnout and low level of selfefficacy. For example they indicated financial issues as the most demanding and problematic reasons of burdening. Moreover, several teachers believed that they had some trouble with the materials and books they taught (10\%), for example "use of inappropriate methodology for the subject being taught is one of the main reasons."

A lack of professional and qualified teachers, educational rules and policies, not positive and friendly atmosphere among colleagues/supervisors and managers, students with behavior problem and not qualified supervisors and managers were characteristic of the reasons that were considered as burdening by the teachers.

In addition, data revealed clearly that the majority of teachers reported that modernized work place and being up-todate could be the best solution as one stating that" using internet for being updated on regular basis, taking part in teacher development courses like TESOL, exchange experiences with my fellow teachers".

As the second influential contribution for removing or preventing burnout, $21 \%$ complained about their low salaries. They compared their salaries to the cost of living.

The third frequently mentioned solution (13\%) for burdening was asking for help from friends...and observing other classes. One teacher commented, "I can get some help from professional people."

\section{CONCLUSION}

To summarize, the data analysis revealed that teachers consider different factors as the main cause of burnout among teachers. They have different priorities and this range of priorities leads to considering different factors as the underlying causes of burnout among teachers. It seems that different teachers get burned out differently and it makes the task more grueling. All the aforementioned factors have to be considered by all policy makers, managerial sectors and even syllabus designers in all processes of their decision making. To obliterate all these underlying causes, cooperation among different educational sections seems necessary. It means to reduce the amount of burnout among teachers the involvement of different groups is necessary.

Moreover, according to the findings of this study, it is not reasonable and fair to critic a teacher according to only one of his/her qualities. Therefore, knowing how individual differences in teachers result in various performances in the class are of important issues to overcome teachers' problems. Further research is needed to include a comparison of teachers in private and public settings, since the teachers studied in this research were from private institutes. 


\section{ACKNOWLEDGMENT}

We are particularly grateful to all EFL teachers of the private language institutes who participated in the research. We also thank Dr. Kargozari for his helpful comments and insights.

\section{REFERENCES}

[1] Akbari R, Moradkhani S. (2010). Iranian English teachers' self-efficacy: Do academic degree and experience make a difference? Pazhuhesh-e Zabanha-ye Khareji.56, 25-47.

[2] Bandura, A. (1997). Self-efficacy: The exercise of control. New York: W.H. Freeman

[3] Bandura, A. (2006). Adolescent development from an agentic perspective. In F. Pajares, \& T. Urdan (Eds.), Self-efficacy beliefs of adolescents (pp. 1e43).Greenwich, Connecticut: Information Age Publishing.

[4] Borg, M. G., \& Riding, R. J. (1991).Toward a model for the determinants of occupational stress among schoolteachers. European Journal of Psychology of Education, 6, 355-373.

[5] Britt, P. M. (1997, November). Perceptions of beginning teachers: Novice teachers reflect upon their beginning experiences. Paper presented at the annual meeting of the Mid-South Educational Research Association, Memphis, TN. ERIC document reproductive service no. ED 415218.

[6] Bruce, S., P. (2009). Recognizing stress and avoiding burnout. Currents in Pharmacy Teaching and Learning 1, $57-64$.

[7] Campbell, J. (1993). A Comparison of teacher efficacy for pre and in service teachers in Scotland and America. Education. 177, 1.

[8] Chacón, C. T. (2005). Teachers' perceived efficacy among English as a foreign language teachers in middleschools in Venezuela. Teaching and Teacher Education, 21(3), 257-272.

[9] Chester, M., D. (1996). Beaudin BQ. Efficacy beliefs of newly hired teachers in urban schools. American Educational Research Journal.33(1), 233-257.

[10] Dembo, M. H. \& Gibson, S. (1985). Teachers' sense of efficacy: An important factor in school improvement. The Elementary School Journal, 86(2), 173-184

[11] Devos, C., Dupriez, V., \& Paquay, L. (2012). Does the social working environment predict beginning teachers' self-efficacy and feelings of depression? Journal of Teaching and Teacher Education, 28, 206-217.

[12] Dewey, J. (1903). Democracy for the teacher. Elementary School Teacher. Reprinted. In: S. I. Brown, \& M. E. Finn (Eds.). (1998). Readings from progressive education: A movement and its professional journal, Vol. 1 (pp. 199- 201). Lanham, MD: University Press of America.

[13] Freudenberger, H. (1974). Staff burnout. Journal of Social Issues, 30, 159-165.

[14] Ganser, T. (1999, April). Reconsidering the relevance of Veenman's (1984) metaanalysis of the perceived problems of beginning teachers. Paper presented at the annual meeting of the American Educational Research Association, Montreal, Quebec. ERIC document reproductive service no. ED 429964.

[15] Gavora, P. (2011). Measuring the Self-efficacy of in-service Teachers in Slovakia. Orbis Scholae.

[16] Ghaith, G., \& Shaaban, K. (1999). The relationship between perceptions of teaching concerns, teacher efficacy, and selected teacher characteristics. Teaching and Teacher Education 15(5), 487-496.

[17] Ghasemi, B., hashemi, M. (2011). The study of the characteristics of successful english language teachers from the view point of the english language students of Islamic Azad University, Hamedan Branch. Journal of Social and Behavioral Sciences, 28, $411-415$.

[18] Goddard, R. D., Hoy, W. K. \& Hoy, A. W. (2000). Collective teacher efficacy: Its meaning, measure, and impact on student achievement. American Educational Research Journal, 37(2), 479-507.

[19] Gold, Y. (1985). The relationship of six personal and life history variables to standing on three dimensions of the Maslach Burnout Inventory in a sample of elementary and junior high school classroom teachers. Educational and Psychological Measurement, 45, 377-387.

[20] Golembiewski, R. T., Munzenrider, R., \& Carter, D. (1983). Phases of progressive burnout and their work site covariants: Critical issues in OD research and praxis. Journal of Applied Behavioral Science, 19, 461-481.

[21] Hakanen, J. J., Bakker, A. B., \&Schaufeli,W. B. (2006). Burnout and work engagementamong teachers. Journal of School Psychology, 43, 495_513.

[22] Hebert, E., \&Worthy, T. (2001). Does the first year of teaching have to be a bad one? A case study of success. Teaching and Teacher Education, 17(8), 897_911.

[23] Hoy, W. K. (1996). The organizational climate of middle schools. Journal of Educational Administration, 34, 41-59.

[24] Iwanicki, E. F., \& Schwab, R. L. (1981). A cross-validation study of the Maslach Burnout Inventory. Educational and Psychological Measurement, 41, 1167-1174.

[25] Jennett, H. K., Harris, S. L., \& Mesibov, G. B. (2003).Commitment to philosophy,teacher efficacy, and burnout among teachers of children with autism. Journal of Autism and Developmental Disorders, 33, 583_593.

[26] Leithwood, K., Menzies, T., Jantzi, D., \& Leithwood, J. (1996). School restructuring, transformational leadership and the amelioration of teacher burnout. Anxiety, Stress and Coping, 9, 199-215.

[27] Markley, T. (2004). Defining the effective teacher: Current arguments in education. Essays in Education 11(3), 1-14.

[28] Maslach, C., \& Jackson, S. E. (1978). Lawyer burnout. Barrister, 5, 52-54.

[29] Maslach, C., \& Jackson, S. E. (1981). Maslach burnout inventory manual. MountainView, California: CPP, Inc.

[30] Maslach, C., \& Jackson, S. E. (1982). Burnout in health professions: A social psychological analysis. In G. Sanders, \& J. Suls (Eds.), Social psychology of health and illness (pp. 227-251). Hillsdale, NJ: Lawrence Erlbaum.

[31] Maslach, C., \& Jackson, S. E. (1986). Maslach burnout inventory manual (2nd ed.). Palo Alto, CA: Consulting Psychologist Press. 
[32] Melnick, S. A., \& Meister, D. G. (2008). A comparison of beginning and experienced teachers' concerns. Educational Research Quarterly, 31(3), 39_56.

[33] Milner, H. R., \&Woolfolk Hoy, A. (2003). Teacher self-efficacy and retaining talented teachers: a case study of an African American teacher. Teaching and Teacher Education, 19, 263_276.

[34] Murdoch, G. (1997). What makes a good English language teacher? In TESOL Arabia 1997 Third International Conference, vol 11. Conference Proceedings Selected Papers, March. 96_108.

[35] National Center for Education Statistics. (2004). Teacher attrition and mobility: Results from the teacher follow-up survey, 2000-01 (NCES 2004-301).Washington, D.C.: U.S. Government Printing Office, by Luckens, M.T., Lyter, D. M., Fox, E.E. \& Chandler, K.. Retrieved July 2, 2010, from http://nces.ed.gov/pubsearch/pubsinfo.asp?3pubid1/42007307.

[36] National Commission on Teaching and America's Future. (2003). No dream denied: A pledge to America's children. Washington, D.C.: US.

[37] Norton, M. S. (1998). Teacher absenteeism: A growing dilemma in education. Contemporary Education, 69, 95-99. R.K. Henson / Teaching and Teacher Education 17 (2001) 819-836 835

[38] Pines, A. M. (2002). Teacher burnout: a psychodynamic existential perspective. Teachers \& Teaching, 8(2), 121_140.

[39] Pines, A., \& Maslach, C. (1978). Characteristics of staff burnout in mental health settings. Hospital and Community Psychiatry, 29, 233-237.

[40] Raquepaw, J. M., \& Miller, R. S. (1989). Psychotherapist burnout: A componential analysis. Professional Psychology: Research and Practice, 20, 32-36.

[41] Rentoul, A. J., \& Fraser, B. J. (1983). Development of a schoollevel environment questionnaire. Journal of Educational Administration, 21, 21-39.

[42] Roness, D., \& Smith, K. (2010). Stability in motivation during teacher education. Journal of Education for Teaching, 36(2), 169-185.

[43] Rots, I., Aelterman, A., Vlerick, P., \& Vermulen, K. (2007). Teacher education, graduates' teaching commitment and entrance into the teaching profession. Teaching and Teacher Education, 23(5), 543-556.

[44] Rotter, J. B. (1966). Generalized expectancies for internal versus external control ofreinforcement. Psychological Monographs, 80,1_28.

[45] Schonfeld, I. S. (1992). A longitudinal study of occupational stressors and depressive symptoms in first-year female teachers. Teaching and Teacher Education, 8(2), 151_158.

[46] Schutz, P. A., \& Zembylas, M. (2009). Advances in teacher emotion research: The impact on teachers' lives. New York, NY: Springer Publishing.

[47] Smith, K., \& Lev-Ari, L. (2005). The place of the practicum in pre-service teacher education: the voice of the students. AsiaPacific Journal of Teacher Education, 33 (3), 289-302.

[48] Stevens, G. B., \& O’Neill, P. (1983). Expectation and burnout in the developmental disabilities field. American Journal of Community Psychology, 11, 615-627.

[49] Trent, L. M. Y. (1997). Enhancement of the school climate by reducing teacher burnout: Using an invitational approach. Journal of Invitational Theory and Practice, 4, 103-114.

[50] Tschannen-Moran, M., \&Woolfolk-Hoy, A. (2001). Teacher efficacy: Capturing an elusive construct. Teacher and Teacher Education, 17, 783-805.

[51] Vaezi S, Fallah N. (2011).The relationship between self-efficacy and stress among Iranian EFL teachers. Journal of Language Teaching and Research. 5(2):1168-1174. (doi:10.4304/j1tr.2.5.1168-1174).

[52] Veenman, S. (1984). Perceived problems of beginning teachers. Review of Educational Research, 54(2), 143 _178.

[53] Wilson, S. M., Floden, R. E., \& Ferrini-Mundi, J. (2002). Teacher preparation research. An insider's view from the outside. Journal of Teacher Education, 53(3), 190-204.

[54] Zamani Rad, A., \&Rohany, N. (2010).Burnout and Career Self Concept among Teachers in Mashhad, Iran. Journal of Procedia Social and Behavioral Sciences 7(C), 464-469.

Mona Tabatabaee Yazdi, is M.A. in ELT from Azad University of Torbat-e-Heydarieh, Iran. She has been teaching English since 2007. She has published some papers in different areas of EFL, and given presentations on TEFL at some national and international conferences. Her areas of interest are language testing, teacher education, and e-learning

Khalil Motallebzadeh is assistant professor at the Islamic Azad University (IAU) of Torbat-e-Heydarieh and Branch, Iran. As for his professional background, he has been teaching English since 1985 and at present is assistant professor at Islamic Azad University (IAU) of Torbat-e-Heydarieh and Mashhad Branches, Iran. He has been a visiting scholar at the University of Illinois at Urbana Champaign (UIUC) in 2007-2008. Khalil Motallebzadeh has published several papers in different areas in national and international journals, and given presentations on TEFL at many international conferences. He is especially interested in language testing, teacher education, and e-learning.

Hamid Ashraf, Ph.D. in ELT from University of Pune (India) has been a member of faculty at English Department, Islamic Azad University, Torbat-e-Heydarieh, Iran since 1996. He has worked on language learning skills, testing, critical thinking, language learners' characteristics, and e-learning through doing research, presenting papers in national and international conferences and authoring a book. 